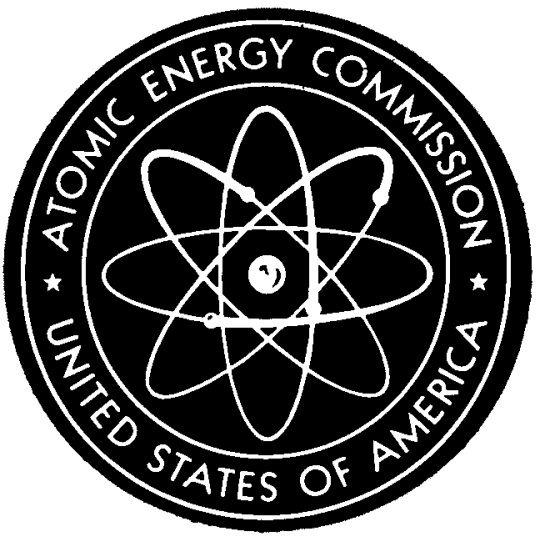

TID-i4844

\title{
CALCULATION OF DISTANCE FACTORS FOR POWER AND TEST REACTOR SITES
}

Technical Information Document

By
J. J. DiNunno
R. E. Baker
F. D. Anderson
R. L. Waterfield

March 23, 1962

Division of Licensing and Regulation, AEC

Washington, D. C. 


\section{DISCLAIMER}

This report was prepared as an account of work sponsored by an agency of the United States Government. Neither the United States Government nor any agency Thereof, nor any of their employees, makes any warranty, express or implied, or assumes any legal liability or responsibility for the accuracy, completeness, or usefulness of any information, apparatus, product, or process disclosed, or represents that its use would not infringe privately owned rights. Reference herein to any specific commercial product, process, or service by trade name, trademark, manufacturer, or otherwise does not necessarily constitute or imply its endorsement, recommendation, or favoring by the United States Government or any agency thereof. The views and opinions of authors expressed herein do not necessarily state or reflect those of the United States Government or any agency thereof. 


\section{DISCLAIMER}

Portions of this document may be illegible in electronic image products. Images are produced from the best available original document. 


\section{NOTICE}

This report was prepared as an account of work sponsored by the United States Government. Neither the United States nor the United States Atomic Energy Commission, nor any of their employees, nor any of their contractors, subcontractors, or their employees, makes any warranty, express or implied, or assumes any legal liability or responsibility for the accuracy, completeness or usefulness of any information, apparatus, product or process disclosed, or represents that its use would not infringe privately owned rights.

This report has been reproduced directly from the best available copy.

^

Available from the National Technical Information Service, U.S. Department of Commerce, Springfield, Virginia 22151.

Price: Paper Copy $\$ 1.00$

Microfiche $\$ 0.95$. 


\section{CALCULATION OF DISTANCE FACTORS FOR POWER AND TEST REACTOR SITES*}

Technical Information Document

\section{By}

J. J. DiNunno

F. D. Anderson

R. E. Baker

R. I. Waterfield

\section{NOTICE}

This report was prepared as an account of work sponsored by the United States Government. Neither the United States nor the United States Atomic Energy Commission, nor any of their employees, nor any of their contractors, subcontractors, or their employees, makes any warranty, express or implied, or assumes any legal liability or responsibility for the accuracy, completeness or usefulness of any information, apparatus, product or process disclosed, or represents that its use would not infringe privately owned rights.

March 23, 1962

Division of Licensing and Regulation

U. S. Atomic Energy Commission

* Second printing--minor editorial changes made from the first printing. 
-

$\checkmark$

:

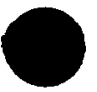




\section{$\underline{\underline{T}} \underline{A} \underline{B} \underline{\underline{L}} \underline{\underline{E}} \quad \underline{O} \underline{\underline{T}} \quad \underline{C} \underline{Q} \underline{\mathbb{N}} \underline{\underline{T}} \underline{\underline{E}} \underline{\underline{N}} \underline{T} \underline{S}$}

Pege

II. INTRODUCTION 3

III. BASIC CRITERIA

IV. POSTULATION OF MAJOR REACTOR ACCIDENT 8

V. ANALYTIGAI METHOD 13

A. Fundamental Assumptions $\quad 14$

B. Inhalation Doss Calculations 18

C. Bxternal Gamme Dose Calculations 25

D. Results 28

VI. COMPARISON OF ANALYTIGAL METHOD TO EXISTING REACTOR SITES 35

VII. APPENDIX 37

A. Relationsh1p of the Sutton Diffusion Parameter and the 37 Generalized Gaussion Parameter

B. Bibllography 38

C. List of Symbols and Definitions 39

REFERENGES 41 


\section{PURPOSE}

It is the intent that this document to provide reference information and guidance on procedures and besic assumptions whereby certain factors pertinent to reactor siting as set forth in Title 10 Code of Federal Regulations Part 100 $(10 \mathrm{CFR} 100)^{(1)}$ can be used to calculate distance requirements for reactor sites which are generally consistent with current siting practices.

For any proposed reactor: the performance experience accumulated elsewhere; the engineering safeguards; the inherent stability and safety features; and the quality of design, materials, construction, management and operation are all important factors that must be included in the evaluation of the suitability of a site.

For a particular site; size, topography, meteorology, hydrology, ease of warning and removing people in times of emergency, and thoroughness of plans and arrangements for minimizing injuries and interference with offsite activities, all enter an evaluation.

Consideration of these as well as other aspects of hazards evaluation involves so many different situations and such complex technological problems that it would be quite impossible to anticipate and answer all questions that will arise.

This technical document sets forth one method of computing distances and exposures, for one general class of reactors. In developing this example conservative assumptions have been intentionally selected.

Designers of reactors are expected to examine all significant aspects of the hazards and safety problem they believe are appropriate to the particular 
situation with which they are dealing. In any case, the designer and/or applicant bears the responsibility for justifying all the assumptions and methods of calculation used in a hazards evaluation. The fact that aspects of the problem are not considered in the example set forth here, does not in any way relieve the designer and/or applicant of the responsibility for carefully examining, in his particular case, every significant facet of the hazards and safety problem. 


\section{INTRODUCTION}

An applicant for a license to construct a power or test reactor is required by Atomic Energy Commission (AEC) regulations, Title 10 Code of Federal Regulations Part 50 (10 CFR Part 50), to submit in support of his application a hazards summary report that includes details pertinent to the site proposed for the reactor. Approval or disapproval is given by the Commission after review and evaluation of the reactor design and the proposed location by the Division of Licensing and Regulation and the Advisory Committee on Reactor Safeguards (ACRS). Such review and evaluation includes an analysis of the consequences of potential accidents.

The probability and consequences of major reactor accidents have been the subject of widespread interest and study since the earliest days of reactor development. To date, however, the technology has not progressed to the point where it is possible to assign quantitative numbers to all the significant factors relative to safety or to predict with surety the probabilities of malfunctioning of engineering features of plant design under all operating conditions that might exist. There is rather general agreement, however, as expressed in the Brookhaven report, "Theoretical Possibilities and Consequences of Major Accidents in Large Nuclear Power Plants", (2) that the probability of a major accident in reactor plants constructed and operated in accordance with general practices now observed is exceedingly small. The following is quoted from the report:

$$
\begin{aligned}
& \text { "As to the probabilities of major reactor accidents, } \\
& \text { some experts believe that numerical estimates of a quantity }
\end{aligned}
$$


so vague and uncertain as the likelihood of occurrence of major reactor accidents has no meaning. They decline to express their feeling about this probability in numbers. Others, though admitting similar uncertainty, nevertheless, ventured to express their opinions in numerical terms.... However, whether numerically expressed or not, there was no disagreement in the opinion that the probability of major reactor accidents is exceedingly low."

This low probability of occurrence is due to both the inherently safe features of reactors and the safeguards that have been engineered into the plants as a part of deliberate and planned effort to insure safety. The question of suitability of a site for a reactor, however, requires consideration not only of the factors influencing the probability of occurrence of an accident, but also the risk in terms of possible exposure of people to the hazardous consequences of such an accident. Although the probability of a serious accident may be primarily a function of facility design and the risk in terms of exposure may be primarily a function of location, the two are not independent. Site characteristics may dictate the inclusion of specific engineered safeguard features and a proposed facility design in turn may have marked influence on the acceptability of the site for location of the reactor.

Values of radiation exposare dose that can be used as reference values in the evaluation of reactor sites have been set forth in $10 \mathrm{CFR} 100$. Considerations that led to the establishment of these reference values and the site criteria in which they are embodied are discussed in the sections that follow. In addition, a hypothetical case is analyzed to illustrate the calculation of distance factors as required by $10 \mathrm{CFR} 100$. 


\section{BASIC CRITERIA}

The AEC has set forth in 10 CFR 100 a number of the factors considered by the Commission in the evaluation of reactor sites and the general criteria used at this time as guides in approving or disapproving proposed sites. One of the factors identified is the following:

"Population density and use characteristics of the site environs, including, among other things, the exclusion area, low population zone, and population center distance."

The guides ( $10 \mathrm{CFR}$ 100.11) also set forth pertinent factors to be considered in estimating the exclusion area, low population zone and population center distance.

Specifically, 10 CFR 100 requires an applicant for a construction permit to determine the following:

"(1) An exclusion area of such size that an individual located at any point on its boundary for two hours immediately following onset of the postulated fission product release would not receive a total radiation dose to the whole body in excess of 25 rem or a total radiation dose in excess of 300 rem to the thyroid from iodine exposure.

(2) A low population zone of such size that an individual located at any point on its outer boundary who is exposed to the radioactive cloud resulting from the postulated fission product release (during the entire period of its pasaage) would not receive a total radiation dose to the 
whole body in excess of $25 \mathrm{rem}$ or a total radiation dose

in excess of 300 rem to the thyroid from iodine exposure.

(3) A population center distance of at least $11 / 3$ times the distance from the reactor to the outer boundary of the low population zone. In applying this guide due consideration should be given to the population distribution within the population center. Where very large cities are involved, a greater distance may be necessary because of total integrated population dose considerations."

In these criteria, two concepts are worthy of particular comment:

\section{Note 1: Exposure Limits}

The whole body dose of 25 rem referred to in the above excerpts from 10 CFR 100 corresponds numerically to the once in a lifetime accidental or emergency dose for radiation workers, which, according to NCRP recommendations (3), way be disregarded in the determination of their radiation exposure status. However, neither its use in the context of this regulation nor that of a correspondingly low internal organ dose (such as, for example, the 300 rem to the thyroid might be considered in this application) is intended to imply that these numbers constitute acceptable emergency doses to the public under accident conditions. Rather, this 25 rem value and the 300 ren thyroid value have been set forth in these guides as reference values which can be used in the evaluation of reactor sites for reactors that reflect through their design, construction and operation an exceedingly low probability for a major accident, and through location and other safeguards against the hazardous consequences of an accident, should one occur, a low probability of public damage from such accidents. These exposure values cannot be considered as being independent from the likelihood of serious accidents nor from considerations of the total number, of persons that might be exposed. They have been set forth as reasonable bases for reactor site evaluations in the context of considerations such as those indicated in Section $v$. of this document. 
Note 2: Population Center Distance

One basic objective of the criteria is to assure that the cumulative exposure dose to large numbers of people as a consequence of any nuclear accident should be low in comparison with what might be considered reasonable for total porulation dose. Further, since accidents of greater potential hazard than those commonly postulated as representing an upper limit are conceivable, although highly improbable, it was considered desirable to provide for protection against excessive exposure doses of people in large centers, where effective protective measures might not be feasible. Neither of these objectives were readily achievable by a single criterion. Hence, the population center distance was added as a site requirement when it was found for several projects evaluated that the specifications thereof would approximately fulfill the desired objectives and reflect a more accurate guide to current siting practices. In an effort to develop more specific guidance on the total man-dose concept, the Commission intends to give further study to the subject. Meanwhile, in recognition of the problem, the population center distance to very large cities may have to be greater than those suggested by these guides. 


\section{POSTULATION OF A MAJOR REACTOR ACCIDENT}

In evaluating proposed reactor sites, the basic safety questions involve the possibility of accidents which might cause radioactivity release to areas beyond the site, the possible magnitudes of such releases and the consequences these might have. Practically, there are two difficult aspects to the estimation of potential accidents in a proposed reactor which affect the problem of site evaluation.

1. The necessity for site appraisal arises early in the life of a project when many of the detailed features of design which might affect the accident potential of a reactor are not settled.

2. The inherent difficulty of postulating an accident representing a reasonable upper limit of potential hazard.

In practice, after systematic identification and evaluation of foreseeable types of accidents in a given facility, a nuclear accident is then postulated which would result in a potential hazard that would not be exceeded by any other accident considered credible during the lifetime of the facility. Such an accident has come to be known as the "maximum credible accident".

For pressurized and boiling water reactors, for example, the "maximum credible accident" has frequently been postulated as the complete loss of coolant upon complete rupture of a major pipe, with consequent expansion of the coolant as flashing steam, meltdown of the fuel and partial release of the fission product inventory to the atmosphere of the reactor building. There may be other combinations of events which could also release significant 
amounts of fission products to the environment, but in every case, for the events described above to remain the maximum credible accident the probability of their occurrence should be exceedingly small, and their consequences should be less than those of the maximum credible accident. In the analysis of any particular site-reactor combination, a realistic appraisal of the consequences of all significant and credible fission release possibilities is usually made to provide an estimate in each case of what actually constitutes the "maximum credible" accident. This estimated or postulated accident can then be evaluated to determine whether or not the criteria set out in $10 \mathrm{CFR} 100$ are met. As a further important benefit, such systematic analyses of potential accidents often lead to discovery of ways in which safeguards against particular accidents can be provided.

Since a number of analyses have indicated that the pipe rupture-meltdown sequence in certain types of water cooled reactors would result in the release of fission products not likely to be exceeded by any other "credible" accident, this accident was designated the "maximum credible accident" (MCA) for these reactors. The remainder of this discussion will refer chiefly to this type of reactor and this type of accident. Corresponding maximum credible accidents can by similar analyses be postulated for gas-cooled, liquid metal cooled, and other types of reactors.

Power and test reactors presently being operated or constructed near inhabited areas, pursuant to licenses issued by the Commission, are enclosed within external containment vessels of some type. This outer barrier to fission product release to the atmosphere has within its enclosure all or a substantial part of the primary plant coolant piping systems representing an inner barrier. Cladding on the fuel provides an additional barrier that acts as a retaining "can" for the fissionable material and the fission products formed. Thus, gross release of fission products to the atmosphere would only occur after the breaching of the two inner barriers, the fuel cladding and the primary system, and then the external barrier, the containment building. 
A gross release of fission products into the reactor building might be initiated by: (1) a nuclear power excursion which would cause pressures in the primary cooling system sufficient to rupture the coolant piping or some part of the system; or (2) a failure of the piping or other parts of the system due to some defect in the materials. In either case, loss of the coolant would set the stage for possible fuel meltdown from the heat of fission product decay.

The rupture of the coolant system from high internal pressures due to uncontrolled internal heat generation would only occur after such failures as the following:

1) reactivity control mechanisms fail to function;

2) high-pressure relief systems fail to perform;

3) pressures exceed rupture limits of the piping material.

These prior failures need not occur for the case of a spontaneous pipe rupture. However, for such a case, the assumption of a complete shear of a pipe represents an extremely unlikely ovent. Nevertheless, assuming that such a break sccurs and coolant is lost, fuel melting would require that:

1) decay heat is sufficient to increase fuel element temperature to the melting point, and

2) safeguard systems usually provided to flond or spray the core with water are either inoperative or insufficient to keep fuel elements from melting.

From such considerations, and from detailed analysis of the inherent self-stabilizing characteristics and engineered "accident prevention" safeguards, assurance is obtained that the likelihood of a major reactor accident is extremely small. Yet such a possibility for a serious accident cannot be completely discounted and the consequences, therefore, must be considered.

If a major release of fission products to the environment should occur, the potential exposure doses to persons off-site are extremely difficult to determine with exactness because of the complex and interwoven technical 
parameters involved. The amount of each kind of radioactive material present in a reactor system can be estimated fairly closely, as a function of the power level history, but the quantity of this material that would be released as a result of an accident is unpredictable. Quantities in the order of 10 per cent of the gross activity have been assumed in the past. Experimental data would indicate these values to be conservative for accidents of the type usually visualized. The exact release can vary so much with the reactor system and with the detailed nature of an accident that the degree of conservatism in the assumptions made in any given case, is not known. Further, there is a multiplicity of possible combinations of the physical and chemical form of the radioactive materials released into the containment vessel and of the ways that atmospheric conditions might cause these radioactive materials to be transported to regions beyond the site boundary.

In accidents of the "maximum credible" type, it is usually assumed that the radioactive materials, along with erosion and corrosion products, would be dispersed in the coolant through melting or rupture of fuel elements, and then find passage to the outer containment barrier through breaches in the coolant system. On breaching, the expansion to a larger volume and a lower pressure in the containment vessel would result in steam, in addition to the gaseous fission products, and production of vapors as well as liquid and solid aerosols of a wide range of sizes. Some ejected materials may conceivably burn on contact with air, and thus increase the volatiles and fractions of fine particles. At the same time, a certain amount of the airborne fission products would be removed by such phenomena as adsorption, deposition, plate-out and steam condensation within the reactor building or contalnment structure. The removal process would be complicated by conversion of normally gaseous fission products into solids by decay, and condensation of volatiles. Removal by adsorption and sèttling processes would be affected by turbulence. Superimposed upon these factors is the radioactive decay resulting in reduction of source strength with time by 
conversion to more stable isotopes. All of these factors make it difficult to determine with any exactness the radioactive content of the air which might leak out of the containment vessel.

The objective of estimating the radioactive inventory within the outer containment barrier is to attain a starting point for calculating the cotential radiological hazard in the surrounding environs. For people in the proximity of the reactor building, the confined radioactive inventory represents a decaying source of direct gamma radiation which is attenuated by such factors as the structural shielding, distance, and shielding by the topography. For those at more distant points, the transport by air of the radioactive materials which might leak from the containment vessel is the major radiological consideration. For air transport, factors such as the physical nature of the material leaking from the containment vessel, release height, particle deposition with distance, wind direction, speed and variability, and air temperature gradients become important in determining the extent of these potential hazards. The meteorological factors will be a function of the region in which the reactor is located as weil as the time of the day and season. Finally, when estimates have been made of the potential concentration of radioactivity likely to result at any distant point from the "maximum credible accident", there still remains a difficult problem of translating atmospheric concentrations into whole body or thyroid ex-• posure doses to people at these points. For internal doses, the controlling ones, there are assumptions to be made about rates of breathing, percentage retention in the body, and cumulative doses to internal organs resulting from retained materials. As the last exercise, there is the problem of establishing some acceptable exposure dose criteria, within the context of this procedural operation, for a comparative measure of the acceptability or unacceptability of the estimated exposures resulting from the hypothetical accident. It is from a study of these complex interwoven technical parameters that the values for the exclusion area, low population zone and population center distance must be determined. 


\section{ANALYTICAL METHOD}

In the procedural method described herein for calculating reactor distances for power and test reactors, the highly complex phenomena involving parameters which may vary over wide ranges of values have been made manageable by simplifying assumptions, specifying that certain secondary factors are to be ignored, and fixing the values of certain key parameters. In utilizing this method, it is recognized that:

1) there is a substantial degree of judgment involved in establishing the basic assumptions and assigning definitive values to variable parameters;

2) the results obtained are approximations, sometimes relatively poor ones, to the result which would be obtained if the effects of the full play of all the variables and influencing factors could be recognized and fixed with certainty--an impossibility in the present state of the art;

3) the net effect of the assumptions and approximations is believed to give more conservative results (greater distances) than would be the case if more accurate calculations could be made.

While this approach represents a considerable simplification in the handling of the many complex phenomena involved, it represents the same very conservative approach to site selection that has characterized such evaluations in the past. 
A. Fundamental Assumptions

The fundamental assumptions upon which the distances are calculated with estimates of the degree of conservatism represented in each case are as follows.

1. Experts agree and experience to date, though limited, confirms that there is only an exceedingly small probability of a serious accident in reactors approved or likely to be approved for construction. ${ }^{(2)}$ The probability is still lower for an accident in which significant amounts of fission products are released into the confined primary coolant system and a great deal lower for accidents wich would release significant quantities of radioactivity from the primary system into the reactor building.

2. It is assumed that the reactor is a pressurized water type for which the maximum credible accident will release into the reactor building 100 percent of the noble gases, 50 percent of the halogens and 1 percent of the solids in the fission product inventory. Such a release represents approximately 15 percent of the gross fission product activity. (11)

3. Fifty percent of the iodines in the containment vessel is assumed to remain available for release to the atmosphere. The remaining fifty percent of the iodines is assumed to absorb onto internal surfaces of the reactor building or adhere to internal components. Rather than the assumed reduction factor of two, it is estimated that removal of airborne iodines by various physical phenomena such as adsorption, adherence and settling could give an effect of 3-10 reduction in the final result. Credit has not been taken for the effects of washdown or filtering from 
protective safeguards such as cooling sprays and internal air recirculating systems. Washdown features and filtering networks could provide additional reduction factors of 10-1000.

4. The release of available (airborne) radioactivity from the reactor building to the environment is assumed to occur at a constant leakage rate of 0.1 per cent per day. The leakage and pressure conditions are assumed to persist throughout the effective course of the accident, which for practical purposes, would be until the iodine activity becomes insignificant. The maximum pressure within the reactor building and the leakage rate would actually decrease with time as the steam condenses from contact with cooling surfaces. By assuming no change in leak rate as a function of pressure drop, it is estimated that the final off-site doses calculated may be too high by factors of 5-10.

5. Atmospheric dispersion of material from the reactor building is assumed to occur according to the well-known relationship developed by $0 . G$. Sutton ${ }^{(4)}$ involving meteorological factors of wind velocity, atmospheric stability, and diffusion parameters. Application of this treatment to reactor hazards analysis was discussed in WASH- $740,{ }^{(2)}$ and AECU-3066. (5) Recently a simplified method of dispersinn calculation has been proposed, by Pasquill ${ }^{(6)}$ and Meade, 7 ) which reflects recent dispersion field trails, as well as current dispersion theories. In the hypothetical situation examined here the latter method gives the same numerical results as the Sutton method for distances out to about seven miles. Beyond this distance, the new method predicts somewhat greater concentrations.

6. The assumption is made that a shift in wind direction does not occur for the duration of the leakage of the fission products from the containment barrier. If leakage from the containment barrier is assumed to occur over a significant time period, (in the order of days) a reduction factor of 2-50 could result from 
shifts in wind directions. Wind meandering from any one centerline direction might also result in a reduction factor of approximately 3 .

7. Atmospheric dispersion is assumed to occur under inversion type weather conditions. For weather conditions which exist for 75 percent or so of the time at most sites, the atmospheric dispersion conditions could be more favorable, by factors of 5-1000. (8)

8. Cloud depletion as ground deposition (particulate fallout) is not assumed during cloud travel. Juch deposition during cloud travel could reduce the low population zone distance by factors of $2-5$.

9. In calculating the direct gamma dose, credit is not taken for shielding by the containment structure and applicable reactor shielding or topography. In some cases it is recognized that such shielding could reduce the direct gamma dose by a factor of $2-1000$.

10. Decay of fission products is assumed while they are confined to the containment building but is not assumed during their transit to the receptor point. The decay enroute is not significant for the conditions of release considered here but would lower the calculated doses slightly if included.

11. In determining the whole body direct gamma dose, only the external gamma dose due to the fission products contained in the reactor building wEs considered significant for the assumed conditions. The whole body direct gamma dose due to the cloud passage for the assumed conditions would contribute only on the order of 1 to 10 percent of the total whole body direct gamma dose at the exclusion and low population zone distances. (5)

Thus, even if the postulated maximum credible accident should occur, the resulting exposure doses would probably be many times lower than those calculated by the indicated method. 
On the other hand, there are potential, conceivable conditions which would result in larger fission product releases than those assumed to be released in the maximum credible accident, and the consequences could be more hazardous. Other potentially more hazardous factors than those represented by the example calculation include the following conditions.

1. Total radioactivity release to the containment vessel could theoretically be up to six times as large as those assumed. Release of long-Jived fission products to the containment vessel could theoretically be up to 99 times as large as that assumed. Such releases would increase doses to the lung, bone, and total body.

2. For some sites, the atmospheric diffusion conditions for a small proportion of time could be worse than those assumed in these calculations. Such diffusion conditions could result in an increase in the inhalation doses.

3. If the external containment structure should be rendered completely ineffective at the outset of the accident, the consequences of the "maximum credible" accident would be increased many orders of magnitude. In such a case, the dose from the cloud and ground contamination could become significant in determining the external dose.

Although the analytical approach presented herein does not take into account the effects of the full play of all the variables and influencing factors, it is considered to be a reasonable procedure that results in distances roughly reflecting current siting practices for water-cooled reactors. The assumptions made can be used as a point of departure for consideration of particular site requirements resulting from evaluation of the characteristics of a particular reactor, its purpose, and the proposed plan of operation. 


\section{B. Inhalation Dose Calculations}

The potential doses to the critical organs as a consequence of inhalation of a portion of the passing cloud were determined in the manner indicated below. For the specific conditions of this example, the thyroid dose is controlling and although the method is quite general, the results of the calculation are specific for the iodine release. If the type and conditions of release were different, the controlling dose could be that to the lung, bone, gut, or other critical organ.

The amount of radioactive material inhaled by a person standing a distance, $d$ (meters), downwind for time, $\tau$ (seconds), on the centerline of a cloud of radioactive material being continuously emitted from a ground level source is given by equation (1).

$$
A_{\tau}=\frac{R Q_{\tau} P_{0}}{\pi^{\tilde{U} \sigma_{y} \sigma_{z}}} \text { curies. ..........(1) }
$$

where:

$A_{\varepsilon}$ is the amount of radioactive material inhaled from the cloud, (curies), during exposure for $\tau$ seconds.

$R$ is the breathing rate, (meter ${ }^{3}$.econd ${ }^{-1}$ ).

$Q_{\tau}$ is the amount of radioactive material in the total cloud, per megawatt reactor power, as it passes the receiver point $d$ meters downind, (curies.M- $w^{-1}$ ), during the time interval $\tau$.

$P_{0}$ is the rated reactor power level, (Megawatts).

i 18 the average wind speed, (meters.second ${ }^{-1}$ ). $\sigma_{y}, \sigma_{z}$ are standard deviations of the cloud centerline concentrations In the vertical and horizontal directions, respectively.*

$$
\sigma_{y}=\frac{1}{\sqrt{2}} c_{y} d^{1-n / 2}, \quad \sigma_{z}=\frac{1}{\sqrt{2}} c_{z} d^{1-n / 2}
$$

$C_{y}, C_{z}$ are the virtual diffusion coefficients in the vertical and horizontal planes, respectively, (meters ${ }^{\mathrm{n} / 2}$ ).

\footnotetext{
- See Appendix A for further discussion.
} 
n is the stability parameter, (dimensionless).

d is the distance downwind, (meters).

Equation (1) is the time integrated expression resulting from the O. G. Sutton model of atmospheric diffusion, neglecting depletion of the cloud either by radioactive decay or scavenging during transit, multiplied by the breathing rate.

Meteorological parameters were selected to be indicative of slow dispersion at a rate estimated to occur at a reasonable frequency. Such conditions could be expected to apply between 15 percent and 25 percent of the time in most areas of the United States. They would correspond closely to Pasquill's type F, stable dispersion regime, which has a frequency of occurrence (in England) in this range, according to Beattie. (9) parameter values used were:

$$
\begin{aligned}
& \bar{u}=1 \text { meter.sec }{ }^{-1} \\
& c_{y}=0.40 \text { meters } n / 2 \\
& c_{z}=0.07 \text { meters } n / 2 \\
& n=0.5 \\
& \sigma_{y}=\left[1 / 2 c_{y}^{2} d^{2-n}\right]^{1 / 2}=\frac{0.40}{\sqrt{2}} d^{0.75} \\
& \sigma_{z}=\left[1 / 2 c_{z}^{2} d^{2-n}\right]^{1 / 2}=\frac{0.07}{\sqrt{2}} d^{0.75}
\end{aligned}
$$

The "source term", $Q_{\tau}$, in equation (1) will be dependent upon the amount of radioactive material which has accumulated in the reactor during operation. A simplified formula for the reactor inventory, $q_{t}$, for a specific isotope is given by equation (2).

$$
\begin{aligned}
& q_{t}=\frac{p_{0} \times 3.2 \times 10^{16} \times \gamma_{i}\left(1-e^{\left.-\lambda_{r} T_{0}\right)}\right.}{3.7 \times 10^{10}} \\
& q_{t}=0.865 \times 10^{6} P_{0} \gamma_{i}\left(1-e^{-\lambda_{r} T_{0}}\right)(\text { curies }) \ldots \ldots . . . .
\end{aligned}
$$

Where:

$$
\begin{aligned}
& q_{t} \text { is the amount of isotope type } i \text { contained by the reactor } \\
& \text { at shutdown, (curies). } \\
& p_{0} \text { is the rated reactor power level, (Megawatts). }
\end{aligned}
$$


$3.2 \times 10^{16}$ is the number of fissions.second ${ }^{-1}$.megawatt ${ }^{-1}$.

$\gamma_{i}$ is the fission yield, (atoms ${ }_{i}$ fission $^{-1}$ ).

$\lambda_{r}$ is the radiological decay constant for the isotope, equal to $\frac{0.693}{T},\left(\right.$ seconds $\left.^{-1}\right)$.

$T_{r}$ is the radiological half-life for the isotope, (seconds ${ }^{-1}$ ).

To is the time interval during which the reactor has operated, (seconds).

$3.7 \times 10^{10}$ is the number of disintegrations. sec $^{-1}$. curie ${ }^{-1}$.

When the reactor has been operated for a time interval such that $\left.T_{0}\right) T_{r}$, the term $-\lambda_{r} T_{0}$ becomes insignificant and the resulting formula for the "saturation" inventory, $q_{8}$, is given by equation ( 3 ).

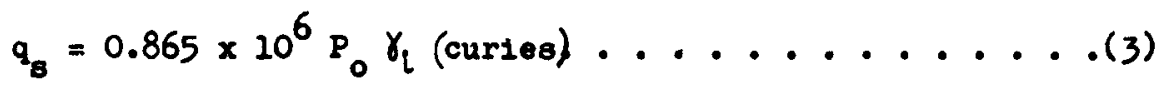

Note that this is only true when $T_{0} \gg T_{r}$, and therefore does not hold for very long-lived isotopes. The approximation is adequate for iodines but inadequate for Sr-90. Saturation values for the several iodine isotopes per Megawatt are given in Table I.

Table I. Saturation Inventory of Iodine Isotopes

\begin{tabular}{ccccc} 
Isotope & $\begin{array}{c}\lambda_{x}(10) \\
\left(\mathrm{sec}^{-1}\right)\end{array}$ & $\frac{Y_{\text {Yield }}(11)}{(\%)}$ & $\begin{array}{c}{\left[\mathrm{q}_{\mathrm{s}} / \mathrm{P}\right]} \\
\text { (curies/Mm) }\end{array}$ \\
\cline { 2 - 3 } 131 & $9.96 \times 10^{-7}$ & 2.9 & $2.51 \times 10^{4}$ \\
132 & $8.26 \times 10^{-5}$ & 4.4 & $3.81 \times 10^{4}$ \\
133 & $9.20 \times 10^{-6}$ & 6.5 & $5.63 \times 10^{4}$ \\
134 & $2.20 \times 10^{-4}$ & 7.6 & $6.58 \times 10^{4}$ \\
135 & $2.86 \times 10^{-5}$ & 5.9 & $5.10 \times 10^{4}$
\end{tabular}

The amount of a specific isotope, $Q_{\tau}$, per Megawatt power, which is released from the reactor building to the atmosphere during the time interval, $\tau$, assuming constant leak rate and radioactive decay only until release, is given by equation (4). 


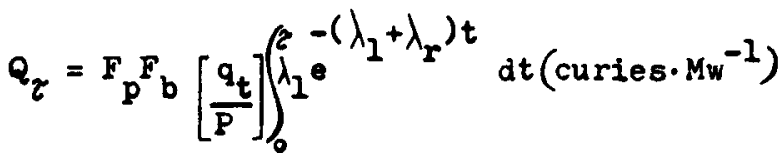

$$
\begin{aligned}
& \left.Q_{r}=F_{p} F_{b}\left[\frac{q_{t}}{p}\right] \frac{\lambda_{1}}{\lambda_{1}+\lambda_{r}}\left[1-e^{-\left(\lambda_{1}+\lambda_{r}\right) \tau_{2}}\right] \text { (curies } \cdot M^{-1}\right) \ldots . \text { (4) }
\end{aligned}
$$

Where: $P$ is unit reactor power (one megawatt).

$F_{p}$ is the fraction of the isotope released from the primary containment system to the building.

$F_{b}$ is the fraction of the isotope which remains airborne and available to be released from the building to the atmosphere.

$q_{t}$ is given by equation (2).

$\lambda_{1}$ is the rate of leakage from the reactor building to the atmosphere, ( seconds $^{-1}$ ).

$\lambda_{r}$ is the radiological decay constant, (seconds ${ }^{-1}$ ).

$\mathcal{Z}$ is the time interval since the start of release during which exposure is assumed to take place, (seconds).

Consideration is given to a reactor which has been operated for a sufficiently long time period that saturation values, $q_{s}$, for the iodine isotopes may be assumed in equation(4). Furthermore, because the radi1 for establishing the limit of the exclusion area and the low population zone are determined by the doses resulting from two hour and infinite exposure, respectively, $\tau$ may be assumed to be 7200 seconds and infinity.

Two forms of the equation are therefore necessary for the evaluation. For exclusion distance:

$$
\left.Q_{t}=F_{p} \times F_{b} \times\left[\frac{q_{B}}{p}\right] \frac{\lambda_{1}}{\lambda_{1}+\lambda_{r}} L^{-e^{-\left(\lambda_{1}+\lambda_{r}\right) 7200} \lambda(\text { curies.Mw }}{ }^{-1}\right) .
$$

For low population zone distance:

$$
\left.Q_{t}=F_{p} \times F_{b} \times\left[\frac{q_{8}}{p}\right] \frac{\lambda_{1}}{\lambda_{1}+\lambda_{r}} \text { (curies.Mw }{ }^{-1}\right) \ldots \ldots . . . . .(6)
$$

The model assumed in developing equation (4) is somewhat oversimplified because it assumes that the fission product is formed directly by fission 
process rather than through decay. Actually, most of the iodine isotopes are formed from the decay of tellurium or, as is generally the case, from the decay of antimony and tellurium. The actual formation is of the type $A \rightarrow B \rightarrow C$ rather than formation of $C$ directly. When the half lives of the precursors are short compared to that of the iodine considered, the effect of the precursors may be ignored and the model is adequate, but when the half life of one or more of the precursors is long compared to the lodine isotope considered, that half life will be the controlling factor in the decay chain after shutdown and the source determination must consider this factor. In the case of $I^{132}$, the complete decay chain and half lives involved are:

$$
\mathrm{Sb}^{132}(1.9 \text { minute }) \rightarrow \mathrm{Te}^{132}(77 \text { hour }) \rightarrow \mathrm{I}^{132}(2.4 \text { hour })
$$

If the reactor has been in operation sufficiently long to establish radiological equilibrium, the activity of the $\mathrm{Te}^{132}$ and the $\mathrm{I}^{132}$ are equal. Since the activity of $\mathrm{I}^{132}$ after reactor shutdown will be determined by the decay rate of the $\mathrm{Te}^{132}$, equations (4h (5h) and (6) may be used to determine the $\mathrm{I}^{132}$ source terms if the decay constant of the $\mathrm{Te}^{132}$ is used in place of the decay constant of $\mathrm{I}^{132}$. A more exact determination of the source term for $I^{131}$ would also consider that amount which would be produced from the $\mathrm{Sb}^{131} \rightarrow \mathrm{Te}^{131}$ chain subsequent to shutdown. The amount is relatively insignificant and the calculation would needlessly complicate the example.

Values for $Q_{\tau}$ for the exclusion and low population distance can be readily determined because values for all the factors have been given or calculated. Table II contains a listing for each of the iodine isotopes and the two time periods involved using the values:

$$
\begin{aligned}
F_{p} & =0.5, \\
F_{b} & =0.5, \\
\lambda_{1} & =0.1 \% \text { day }^{-1} . \\
& =0.001 \text { day }^{-1}, \\
\lambda_{1} & =1.16 \times 10^{-8} \mathrm{sec}^{-1} .
\end{aligned}
$$


The breathing rate, $\underline{R}$, in equation ( 1 ) is also a variable. The "standard $\operatorname{man}^{\prime \prime}(10)$ is considered to breathe 20 meters ${ }^{3}$.day ${ }^{-1}$; half during the active 8 hours and the remaining half during his relatively inactive or resting

\section{Table II Amount of Iodine Released in Time $\tau$}

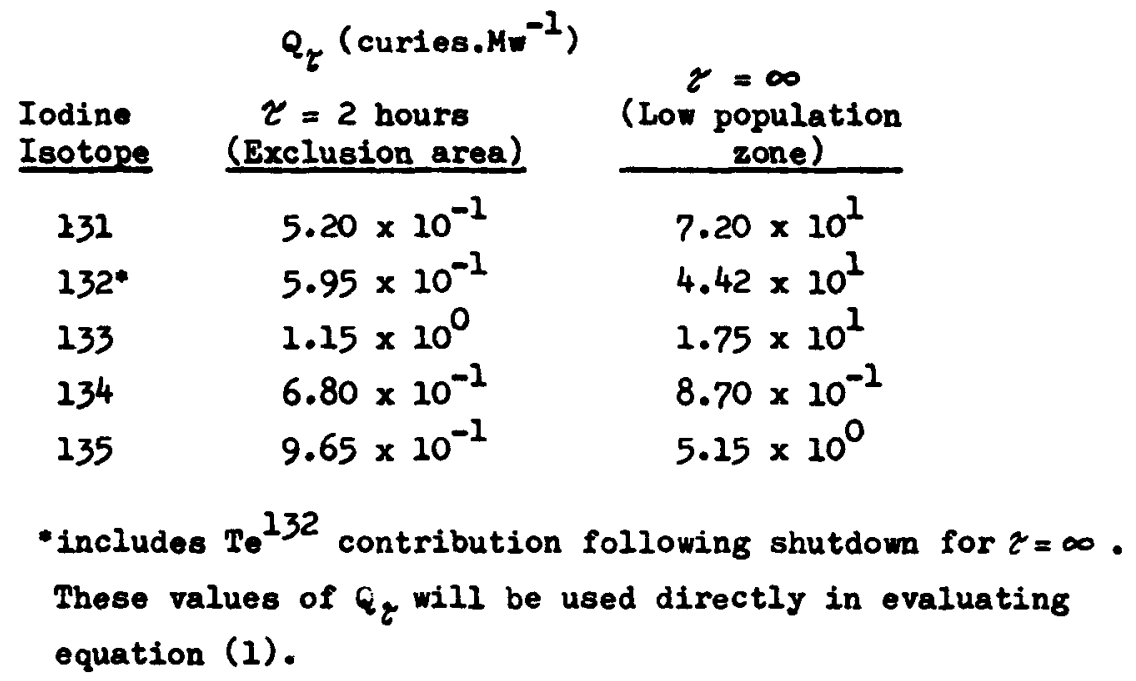

hours. Since concern for personnel in the exclusion zone is based on two hours of inhalation, consider the breathing rate to be characteristic of the active portion of the normal work day,

$$
R=10 \text { meters }{ }^{3} / 8 \text { hours }=3.47 \times 10^{-4}\left(\mathrm{~m}^{3} \cdot \sec ^{-1}\right)
$$

For the low population zone, the average breathing rate is assumed,

$$
R=20 \text { meters }{ }^{3} / 24 \mathrm{hrs}=2.32 \times 10^{-4}\left(\mathrm{~m}^{3} \cdot \sec ^{-1}\right)
$$

Since values have been given or calculated for all factors in equation (1), the amount inhaled, $A_{\tau}$, can be determined for various distances, $d$, downwind. When the amount inhaled of a specific isotope is determined, the dose to the critical organ which will be delivered by this amount can be calculated.. The dose rate, $D^{\prime}$, to the critical organ such as the thyroid at any time subsequent to the inhalation is given by equation (7). 


$$
\begin{aligned}
& D^{\prime}\left(\text { rads.sec }{ }^{-1}\right)=A_{\tau}(\text { curies }) \times 3.7 \times 10^{10}\left({\text { dis. } 80 c^{-1} \cdot \operatorname{curie}}^{-1}\right) \\
& \times f_{a} \times \mathrm{E}\left(\text { Mer.dis }{ }^{-1}\right) 1.6 \times 10^{-6}\left(\mathrm{ergs}^{\mathrm{M}} \mathrm{Mev}^{-1}\right) \mathrm{e}^{-\lambda_{e} t} \\
& +m(g r a m s) 100\left(\text { ergs } \cdot \mathrm{gm}^{-1} \cdot \mathrm{rad}^{-1}\right) \\
& =\frac{5.92 \times 10^{2} A_{t} E_{a} \mathrm{De}^{-\lambda_{e}^{t}}}{m}(\mathrm{rads.8ec}-1) . . .(7)
\end{aligned}
$$

Where:

$$
\begin{aligned}
& A_{\tau} \cdot \text { is given by equation (1). } \\
& f_{a} \text { is the fraction of the amount inhaled which is deposited in the } \\
& \text { critical organ. } \\
& \text { E is the effective energy absorbed by the critical organ per dis- } \\
& \text { integration, (Mev). } \\
& \lambda_{0}=\lambda_{r}+\lambda_{b}=\frac{0.693}{T_{e}},\left(\sec ^{-1}\right) \text {. } \\
& \lambda_{b} \text { is the biological elimination rate for the isotope, }\left(\sec ^{-1}\right) \text {. } \\
& \text { Te is the effective half life for the isotope in the body, (sec). } \\
& \text { m is the mass of the critical organ, (grams). }
\end{aligned}
$$

And the dose to the critical organ, delivered in time, $T$ is given by equation ( 8 ).

$$
\begin{aligned}
& D_{T}=\int_{0}^{T} D^{\prime} d t \\
& =\frac{5.92 \times 10^{2} A_{r} E_{a}^{E}\left[1-A^{-\lambda_{0}^{T}}\right]}{m \lambda_{0}} \text { (rads) } \\
& D_{T}=\frac{8.54 \times 10^{2}}{A_{\tau}} f_{a} E T_{e}\left[I-e-\frac{0.693}{T_{e}}\right](\text { rads }) \ldots \ldots \text { (8) }
\end{aligned}
$$

When the time, $\mathbb{T}$, (over which the dose is determined) is much greater than the effective half life of the isotopes, the quantity, e- $\frac{0.693 \mathrm{~T}}{\mathrm{~T}_{e}}$, becomes insignificant and the dose to the critical organ is given by equation (9).

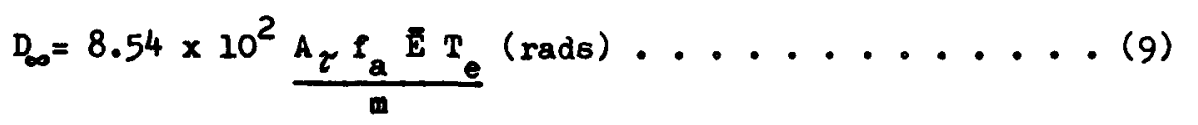

Using equation (9), $\frac{D_{0}}{A_{\tau}}$ has been evaluated for the Lodine isotopes and the values are presented in Table III. 
Table III Dose to Critical Organ Per Iodine Curie Inhaled

\begin{tabular}{|c|c|c|}
\hline $\begin{array}{l}\text { Iodine } \\
\text { Isotope }\end{array}$ & $T_{e}(\sec )$ & $D_{\infty} / A_{\gamma}\left(\right.$ rads.curie $\left.{ }^{-1}\right)$ \\
\hline 131 & $6.57 \times 10^{5}$ & $1.48 \times 10^{6}$ \\
\hline 132 & $8.39 \times 10^{3}$ & $5.35 \times 10^{4}$ \\
\hline 133 & $7.52 \times 10^{4}$ & $4.0 \times 10^{5}$ \\
\hline 134 & $3.11 \times 10^{3}$ & $2.5 \times 10^{4}$ \\
\hline 135 & $2.42 \times 10^{4}$ & $1.24 \times 10^{5}$ \\
\hline
\end{tabular}

\section{External Gamma Dose Calculationg}

The external gamma radiation dose at the exclusion and low population zone distances due to fission products contained in the reactor building were determined in the following manner. The source of radiation was considered to be those fission products released from the primary system to the containment building--krypton, xenon, iodines, and a mixture of the remaining "solid" mixed fission products.

From a point source of radiation-given of $f$ by a specific gamma enitting isotope, the dose rate at a distance, d (meters), away in air is given by equation (10).

$$
\begin{aligned}
& \text { Dose rate, } D^{\prime}\left(\text { rads.sec }{ }^{-1}\right)=F_{p} \times P_{0}(M w) \times\left[\frac{q s}{P}\right]\left(\text { curies.Mw } w^{-1}\right) \\
& \times 3.7 \times 10^{10}\left(\text { dis.sec }{ }^{-1} \cdot \text { curie }^{-1}\right) \times E_{\gamma}\left(\mathrm{Mev} \cdot \text { dis }^{-1}\right) \\
& \times 1.6 \times 10^{-6}\left(\text { ergs.Mev }{ }^{-1}\right) \times \mu_{a}\left(\operatorname{meter}^{-1}\right) B e^{-\mu d} e^{-\lambda_{r} t} \\
& \left.\div 1.293 \times 10^{3} \text { (grams.meter }{ }_{\text {aj.r }}^{-3}\right) \times 10^{2} \text { (ergs.gram }{ }^{-1} \cdot \mathrm{rad}^{-1} \text { ) }
\end{aligned}
$$

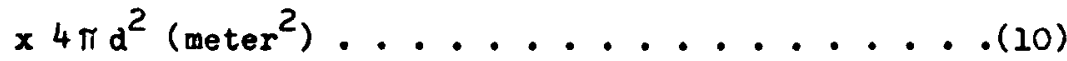

In equation (10), the dose buildup factor, $B$, is expressed by equation $(10 a)^{(12)}$

$$
B=1+k \mu d \ldots \ldots(10 a)
$$

After combining terms, equation (10) can be expressed as

$$
\begin{aligned}
& D^{\prime}=0.985 \times 10^{-12} S_{0} \times F_{p} \times P_{0} \mu_{a} d^{-2}[1+k \mu d] e^{-\mu d} \times e^{-\lambda_{r} t}\left(\text { rads.sec }{ }^{-1}\right) \\
& D^{\prime}=C e^{-\lambda_{r} t}
\end{aligned}
$$


Where:

$S_{0}$ is the initial gamma source strength for the specific lootope at shutdown, (Mev.Sec $\left.{ }^{-1} \cdot \mathrm{Mm}^{-1}\right)$.

$F_{p}$ is the fraction of the isotope released to the reactor bullding.

$P_{0}$ is the rated reactor power level, (Mm).

$\mu_{\mathrm{a}}$ is the energy absorption coefficient, (meter ${ }^{-1}$ ).

is the linear absorption constant, $\left(\frac{\mu-\mu_{a}}{\mu_{a}}\right)$.

$\mu$ is the linear absorption coefficient, (meter ${ }^{-1}$ ).

d is the distance to receptor, (meters).

$\lambda_{r}$ is the radiological decay constant, $\left(\sec ^{-1}\right)$.

$t$ is the time after shutdown, (sec).

C is a constant defined by the equation.

The term, $S_{0}$, combines three terms in equation (11):

$S_{0}=\left[\frac{q_{8}}{P}\right] \times 3.7 \times 10^{10} \times \mathrm{E}_{\gamma}\left(\right.$ Mev.sec $\left.{ }^{-1} \cdot \mathrm{Mw}^{-1}\right)$.

Where:

$\left[\frac{q_{B}}{P}\right]$ is the saturation inventory, (curies.Mm ${ }^{-1}$ ).

$\mathrm{E}_{\gamma}$ is the total gamma energy per disintegration, (Mev.dis ${ }^{-1}$ ).

$3.7 \times 10^{10}$ is the number of disintegrations. sec $^{-1}$.curie $e^{-1}$.

Table IV contains values of $S_{0}, F_{p}, S_{R}, T_{F^{\prime}} \mu_{,} \mu_{a}, k$, and $E_{a r g}$ for the isotopes, the "solid" mixed fission products and the gross fission products assumed to be released to the reactor building. The values of $\mu, \mu_{a}$, and $k$ are energy dependent. Hence, "average" energies, E avg' were selected after reviewing the weighted spectrum for each isotope and mixtures. $(11)$ The term $S_{R}$ is the product of $S_{0}$ and $F_{p}$ for the assumed release conditions.

Integrating the direct gamma dose rate, D', over a specific exposure time yields the direct gamma dose.

$$
\begin{aligned}
& D_{y}=\int_{0}^{t} D_{Y}^{\prime} d t(\operatorname{rad} s) \\
& =c \int_{0}^{t} e^{-\lambda} d t \\
& D_{\gamma}=\frac{c}{\lambda_{r}} L^{-\lambda_{r} z} J(\text { rads }) \ldots \ldots \text { (12) }
\end{aligned}
$$


Table IV. External Gamma Dose Data

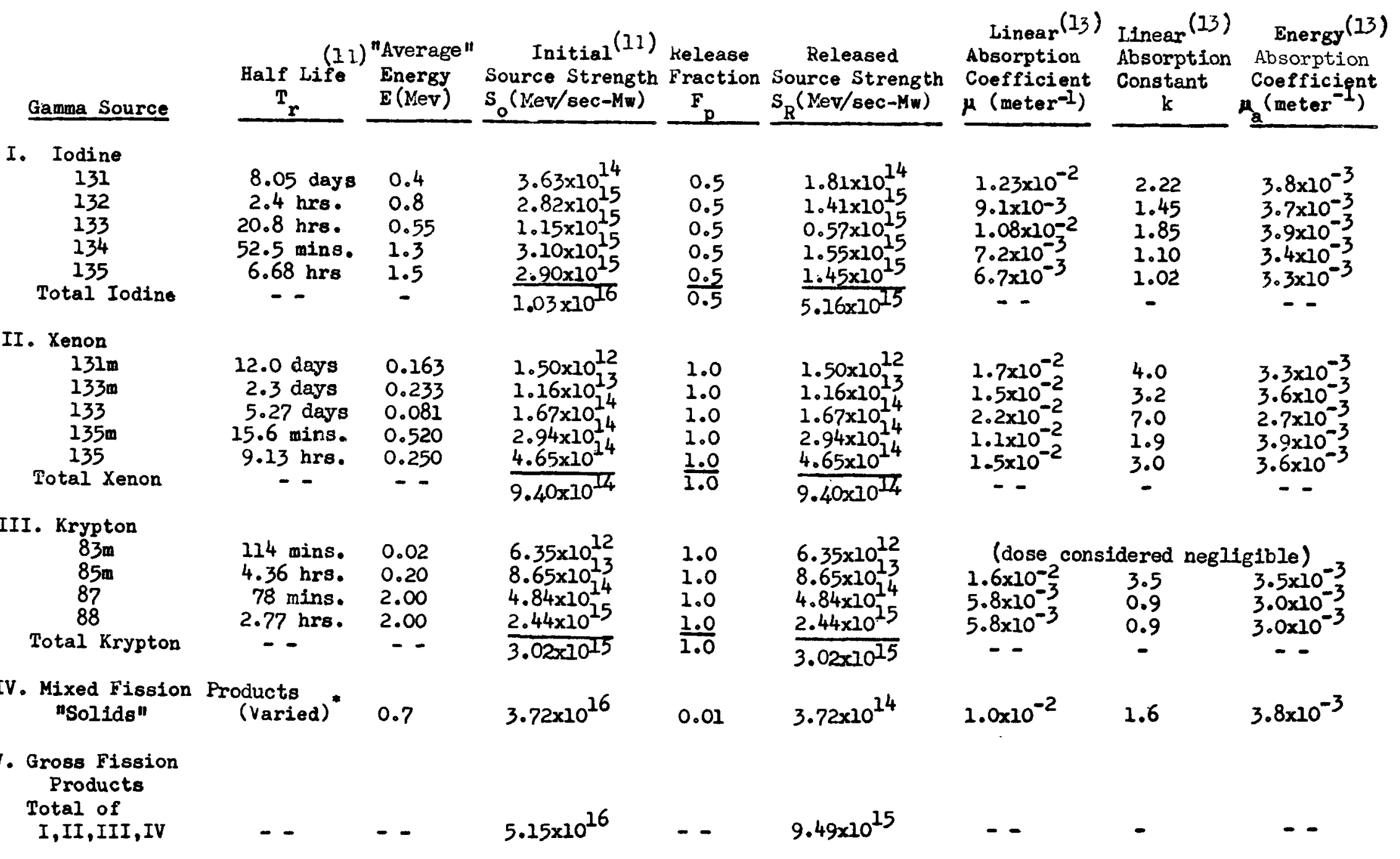

" Solid" Fission Products have an effective half-life of 2.72

hours during the first 2 hours of decay after long-time operation

and have an effective decay rate which follows $t-0.21$ after the

first 2 hours o 
Considering the exclusion distance, the expose time is 2 hours and equation (12) becomes:

$$
D_{\gamma}=\frac{C}{\lambda_{r}}\left[1-e^{-7200 \lambda_{Y}}\right](\text { rads)......... (13) }
$$

and for the low population zone, the exposure time is 30 days, which is several half-lives for the isotopes of the noble gases and iodine. Equation (13) for these isotopes, may be written as:

$$
\mathrm{D}_{\gamma}=\frac{\mathrm{C}}{\lambda_{\mathrm{r}}}(\operatorname{rads}) \ldots \ldots \ldots(14)
$$

In the case of the "solid" mixed fission products the dose for the first two hours was considered to be decaying exponentially with a half-life of 2.72 hours $\left(\lambda_{r}=7.05 \times 10^{-5} \mathrm{sec}^{-1}\right)$ and subsequently as $t^{-0.21}$ based on interpretations of data from Bloweke and Todd. (11)

For the first two hours, the dose was:

$$
\mathrm{D}_{\gamma}=\frac{\mathrm{c}}{\lambda_{r}}\left[1-e^{-\lambda_{r} \tau_{1}}\right](\operatorname{rads}) \ldots \ldots \ldots \ldots
$$

and for the 30 days, the dose was:

$$
\begin{aligned}
& D_{\gamma}=\frac{c}{\lambda_{r}}\left[1-e^{-\lambda_{r} \tau_{1}}\right]+c e^{-\lambda_{r} \tau_{1}} \int_{\tau_{1}}^{\tau_{2}} t^{-0.21} \mathrm{dt} \\
& D_{\gamma}=\frac{c}{\lambda_{r}}\left[1-e^{-\lambda_{r} \tau_{1}}\right]+\frac{c e^{-\lambda_{r} \tau_{1}}}{0.79}\left[\tau_{2}^{0.79}-\tau_{1} 0.79\right](\text { rads). ....... }
\end{aligned}
$$

and since $\tau_{2} \gg \tau_{1}$, equation $(16)$ can be written:

$$
D_{\gamma}=\frac{C}{\lambda_{r}}\left[1-e^{-\lambda_{r} \tau_{1}}\right]+\frac{c e^{-\lambda_{r} \tau_{1}}}{0.79} \tau_{2}{ }^{0.79} \text { (rads)..... (17) }
$$

The total direct gamma dose is the sum of the doses from each of the source terms as determined by equations (13) and (15) for the exclusion area and equations (14) and (17) for the low population zone.

\section{Results}

The results of the calculations performed for the inhalation (lodine) dose and the external gamma dose for the exclusion area ( $\tau=2$ hours) and the low population zone ( $\tau=\infty$ and 30 days, respectively) are presented in 
Table Y. External Gamma Dose Results

Direct Gamma Dose (rads/Mw)

\begin{tabular}{|c|c|c|c|c|c|c|c|c|}
\hline \multirow[b]{2}{*}{$\begin{array}{l}\text { Gamma Source } \\
\text { I. Iodine }\end{array}$} & \multicolumn{4}{|c|}{ Exclusion Radius ( $\tau=2$ hours) } & \multicolumn{4}{|c|}{ Low Population zone ( $\tau=30$ days) } \\
\hline & $100 \mathrm{~m}$ & $300 \mathrm{~m}$ & $600 \mathrm{~m}$ & $1000 \mathrm{~m}$ & $100 \mathrm{~m}$ & $300 \mathrm{~m}$ & $600 \mathrm{~m}$ & $1000 \mathrm{~m}$ \\
\hline $\begin{array}{l}131 \\
132 \\
133 \\
134\end{array}$ & $\begin{array}{l}5.3 \times 10^{-1} \\
2.66 \times 10^{\circ} \\
1.62 \times 10^{\circ} \\
1.61 \times 10^{\circ} \\
2.62 \times 10^{0} \\
\end{array}$ & $\begin{array}{l}1.24 \times 10^{-2} \\
1.02 \times 10^{-1} \\
4.82 \times 10^{-2} \\
8.05 \times 10^{-2} \\
1.39 \times 10^{-1} \\
\end{array}$ & $\begin{array}{l}1.49 \times 10^{4} \\
3.01 \times 10^{-3} \\
9.25 \times 10^{-4} \\
3.85 \times 10^{-3} \\
7.75 \times 10^{-3} \\
\end{array}$ & $\begin{array}{l}4.9 \times 10^{-5} \\
1.24 \times 10^{-4} \\
2.86 \times 10^{-4} \\
\end{array}$ & $\begin{array}{l}7.4 \times 10^{1} \\
5.95 \times 10^{0} \\
2.44 \times 10^{1} \\
2.02 \times 10^{0} \\
1.40 \times 10^{1}\end{array}$ & $\begin{array}{l}1.72 \times 10^{0} \\
2.26 \times 10^{-1} \\
7.25 \times 10^{-1} \\
1.02 \times 10^{-1} \\
7.40 \times 10^{-1}\end{array}$ & $\begin{array}{l}2.06 \times 10^{-2} \\
6.75 \times 10^{-3} \\
1.39 \times 10^{-3} \\
4.84 \times 10^{-3} \\
4.11 \times 10^{-2} \\
\end{array}$ & $\begin{array}{l}9.15 \times 10^{-5} \\
1.08 \times 10^{-4} \\
1.05 \times 10^{-4} \\
1.55 \times 10^{-4} \\
1.52 \times 10^{-3}\end{array}$ \\
\hline 1 & $\overline{9.04 \times 10^{0}}$ & $3.82 \times 10^{-1}$ & $1.57 \times 10^{-2}$ & $4.79 \times 10^{-4}$ & $\overline{1.2 \times 10^{2}}$ & $3.51 \times 10^{0}$ & $7.47 \times 10^{-2}$ & $1.98 \times 10^{-3}$ \\
\hline
\end{tabular}

II. Zenon

\section{$131 \mathrm{~m}$ \\ $133 \mathrm{~m}$ \\ 133 \\ $135 \mathrm{~m}$ \\ 135}

Totel Xenon

III. Krypton

$83 \mathrm{~m}$
$85 \mathrm{~m}$
87
88

Total Krypton

$$
\begin{aligned}
& 5.16 \times 10^{-3} \\
& 3.86 \times 10^{-2} \\
& 6.73 \times 10^{-1} \\
& 1.55 \times 10^{-1} \\
& 1.41 \times 10^{\circ} \\
& \hline 2.28 \times 10^{0}
\end{aligned}
$$

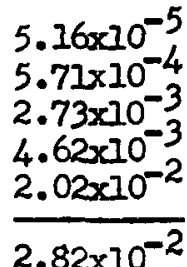

4.

$3.0 \times 10^{-6}$

$1.83 \times 10^{-6}$

$8.25 \times 10^{-5}$

$1.06 \times 10^{-4}$

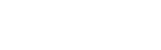

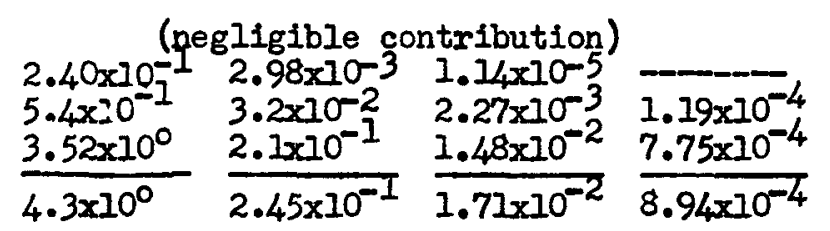

Snegligible
$8.8 \times 10^{-1} \cdot 1.09 \times 10^{-2}$
$8.25 \times 10^{-1} 4.86 \times 10^{-2}$
$\frac{1.03 \times 10^{-1}}{1.2 \times 10^{1}} \frac{6.15 \times 10^{-1}}{6.75 \times 10^{-1}}$

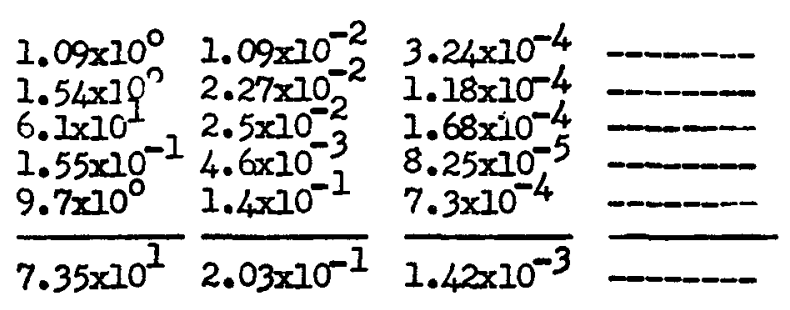

IV. Fission

$$
\text { Products }
$$

$$
\text { "Solids" }
$$

$0^{-1} \quad 2.52 \times 10^{-2} \quad 5.8 \times 10^{-4} \quad 6.0 \times 10^{-6}$

V. Released

Fission

Products

Total

Dose
$1.64 \times 10^{1} \quad 6.8 \times 10^{-1} \quad 3.29 \times 10^{-2} \quad 1.38 \times 10^{-3}$
$1.21 \times 10^{1} \quad 4.05 \times 10^{-1} \quad 9.25 \times 10^{-3} \quad 9.0 \times 10^{-5}$

$2.18 \times 10^{2} \quad 4.79 \times 10^{0} \quad 1.32 \times 10^{-1} \quad 4.53 \times 10^{-3}$ 
Table VI. Inhalation Dose Results

Inhalation Iodine Dose (rads/Mw)

\begin{tabular}{|c|c|c|c|c|c|c|c|c|}
\hline \multirow[b]{2}{*}{ codine } & \multicolumn{4}{|c|}{ Exclusion Radius ( $\tau=2$ hours) } & \multicolumn{3}{|c|}{ Low Popuzation Zone $(\tau=\infty)$} & \multirow[b]{2}{*}{$10^{5} \mathrm{~m}$} \\
\hline & $10^{2} \mathrm{~m}$ & $10^{3} \mathrm{~m}$ & $10^{4} \mathrm{~m}$ & $10^{5} \mathrm{~m}$ & $10^{2} \mathrm{~m}$ & $10^{3} \mathrm{~m}$ & $10^{4} \mathrm{~m}$ & \\
\hline $\begin{array}{l}131 \\
132 \\
133 \\
134\end{array}$ & $\begin{array}{l}6.02 \times 10^{\circ} \\
3.36 \times 10^{-1} \\
3.61 \times 10^{\circ} \\
1.33 \times 10^{-1} \\
9.4 \times 10^{-1}\end{array}$ & $\begin{array}{l}1.94 \times 10^{-1} \\
1.08 \times 10^{-2} \\
1.16 \times 10^{-3} \\
4.28 \times 10^{-2} \\
3.01 \times 10^{-2}\end{array}$ & $\begin{array}{l}6.02 \times 10^{-3} \\
3.36 \times 10^{-4} \\
3.61 \times 10^{-3} \\
1.33 \times 10^{-4} \\
9.4 \times 10^{-4}\end{array}$ & $\begin{array}{l}1.94 \times 10^{-4} \\
1.08 \times 10^{-5} \\
1.16 \times 10^{-4} \\
4.28 \times 10^{-6} \\
3.01 \times 10^{-5}\end{array}$ & $\begin{array}{l}5.6 \times 10^{2} \\
1.24 \times 10_{1}^{1} \\
3.66 \times 10^{1} \\
1.14 \times 10^{-1} \\
3.35 \times 10^{-1}\end{array}$ & $\begin{array}{l}1.79 \times 10^{1} \\
3.98 \times 10^{-1} \\
1.18 \times 10^{\circ} \\
3.66 \times 10^{-3} \\
1.07 \times 10^{-1} \\
\end{array}$ & $\begin{array}{l}5.6 \times 10^{-1} \\
1.24 \times 10^{-2} \\
3.66 \times 10^{-2} \\
1.14 \times 10^{-4} \\
3.35 \times 10^{-3} \\
\end{array}$ & $\begin{array}{l}1.79 \times 10^{-2} \\
3.98 \times 10^{-4} \\
1.18 \times 10^{-3} \\
3.66 \times 10^{-6} \\
1.07 \times 10^{-4}\end{array}$ \\
\hline al Iodine & $1.10 \times 10^{1}$ & $3.55 \times 10^{-1}$ & $1.10 \times 10^{-2}$ & $3.55 \times 10^{-4}$ & $6.12 \times 10^{2}$ & $1.96 \times 10^{1}$ & $6.12 \times 10^{-1}$ & $1.96 \times 10^{-2}$ \\
\hline
\end{tabular}

Values Assumed for Results:

$$
\begin{aligned}
& F_{b}=0.5 \\
& F_{p}=0.5 \\
& \bar{u}^{2}=1 \text { meter. } \sec ^{-1} \\
& c_{y}=0.40 \text { meters } n / 2 \\
& c_{z}=0.07 \text { meters }{ }^{n / 2} \\
& n=0.5 \\
& \lambda_{1}=0.1 \text { percent.day }{ }^{-1}
\end{aligned}
$$


Tables $V$ and VI. Based upon these results, initial estimates of distances for reactors of various power levels have been develojed and are listed in Table VII.

\begin{tabular}{|c|c|c|c|}
\hline \multirow[b]{2}{*}{$\begin{array}{l}\text { Power } \\
\text { Level } \\
\left(\mathrm{Mw} \mathrm{w}_{t}\right) \\
\end{array}$} & \multicolumn{2}{|c|}{ of Various Power Levels } & \multirow[b]{2}{*}{$\begin{array}{c}\text { Population } \\
\text { center } \\
\text { distance } \\
\text { (miles) }\end{array}$} \\
\hline & $\begin{array}{c}\text { Exclusion } \\
\text { area } \\
\text { distance } \\
\text { (miles) } \\
\end{array}$ & $\begin{array}{c}\text { Low nonula- } \\
\text { tion zone } \\
\text { distance } \\
\text { (miles) }\end{array}$ & \\
\hline 1500 & 0.88 & 13.3 & 17.7 \\
\hline 1200 & 0.77 & 11.5 & 15.3 \\
\hline 1000 & 0.67 & 10.3 & 13.7 \\
\hline 900 & 0.63 & 9.4 & 12.5 \\
\hline 800 & 0.58 & 8.5 & 11.5 \\
\hline 700 & 0.53 & 8.2 & 10.9 \\
\hline 600 & 0.48 & 7.2 & 9.6 \\
\hline 500 & 0.43 & 6.5 & 8.7 \\
\hline 400 & 0.37 & 5.4 & 7.2 \\
\hline 300 & 0.31 & 4.5 & 6.0 \\
\hline 200 & 0.29 & 3.4 & 4.5 \\
\hline 100 & 0.25 & 2.2 & 2.9 \\
\hline 50 & 0.21 & 1.4 & 1.9 \\
\hline 10 & 0.13 & 0.5 & 0.7 \\
\hline
\end{tabular}

The estimated radii for power reactors are graphically represented in Figures 1 and 2. For the exclusion distance, doses from both direct gamma radiation from the reactor building and from iodine in the cloud escaping from the reactor building were calculated, and the distance established on the basis of the effect requiring the greater isolation. Figure 1 shows the thyroid and whole body doses for various power levels. Under the conditions assumed, the doses resulting from the inhalation of the isotopes of iodine are controlling for the low population zone distance and population center distance. However, it is possible that such may not always be the case and this should be checked for each case under consideration. The low population zone distance results from 


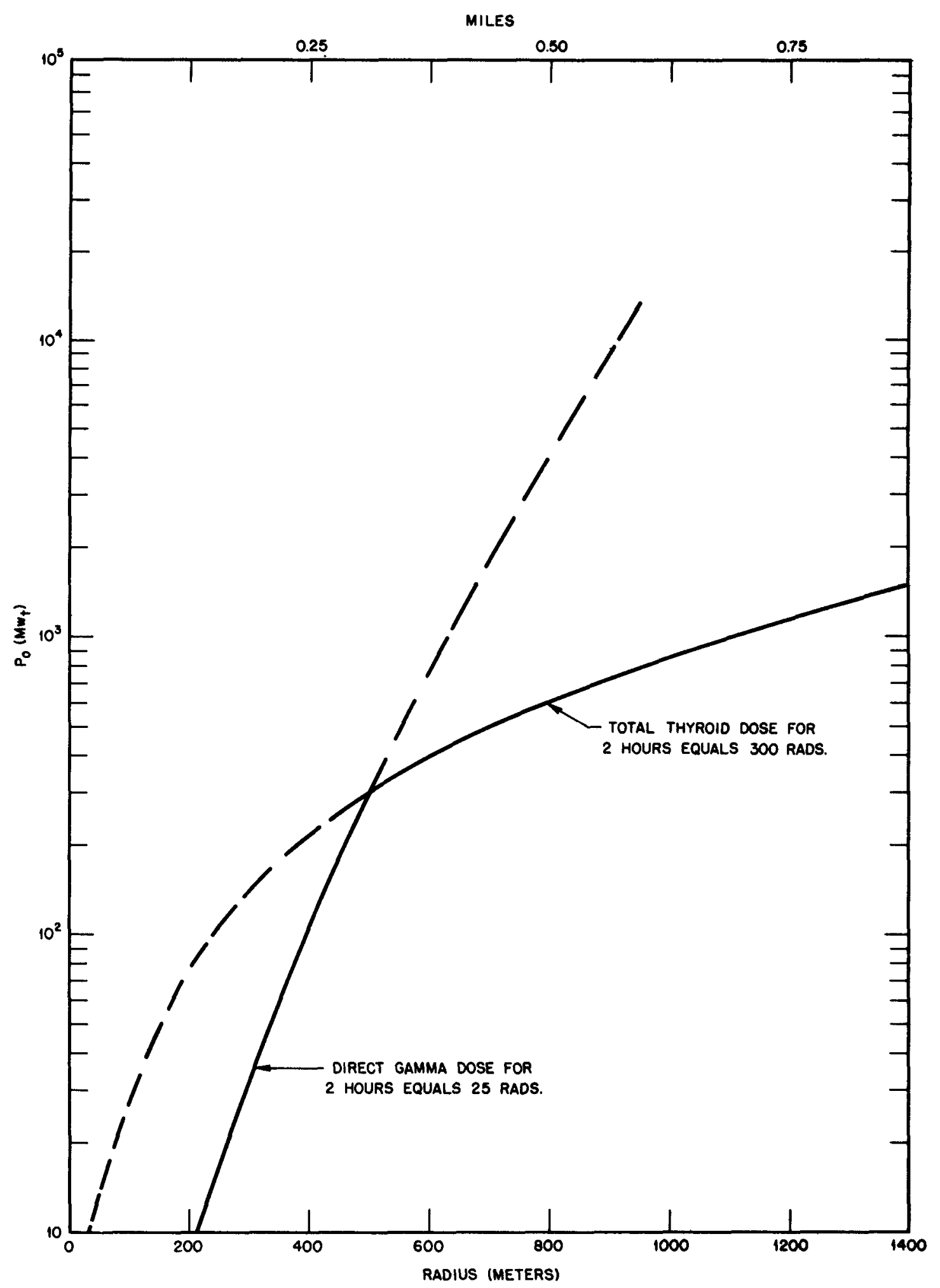

Figure 1. Exclusion Radius Determination. 


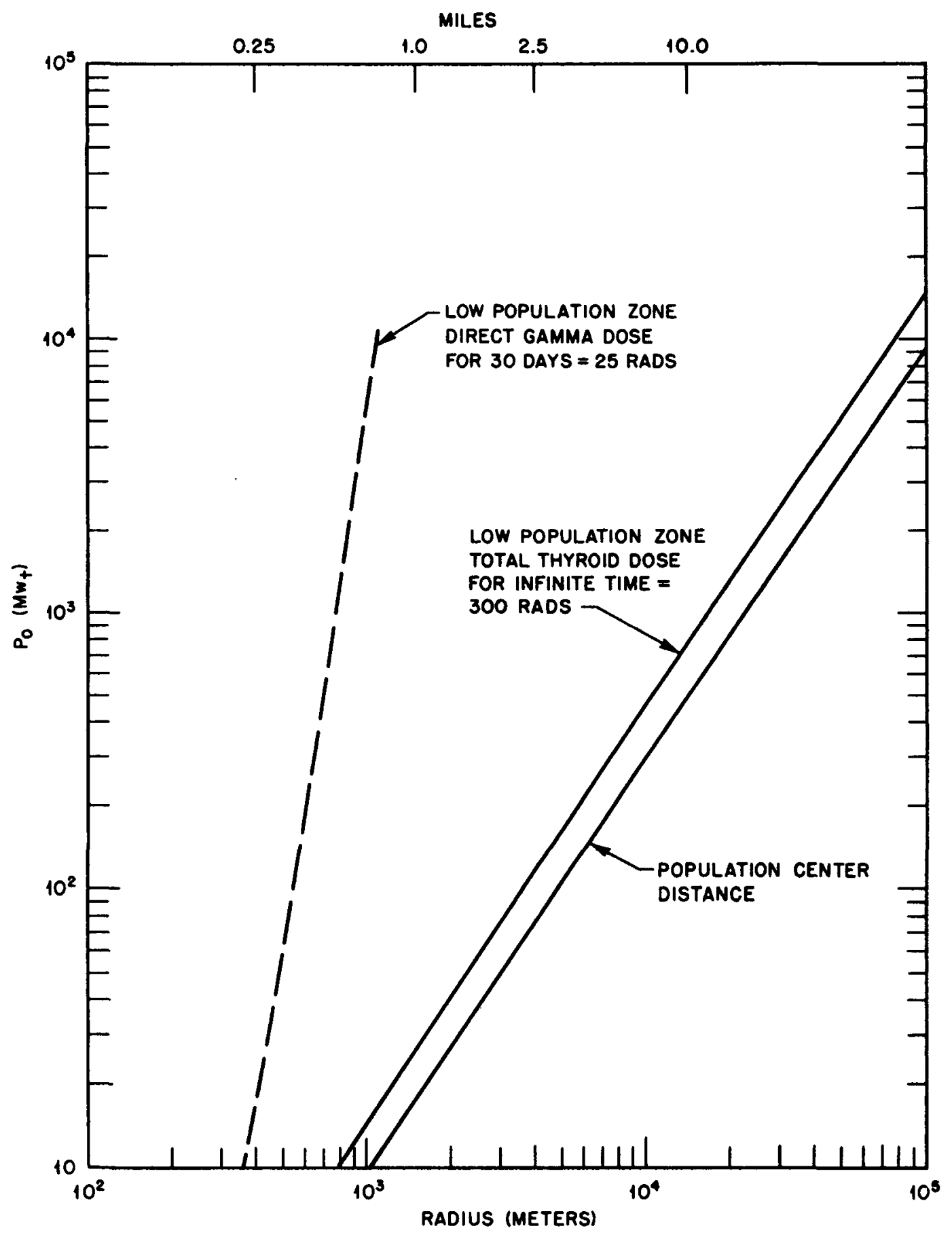

Figure 2. Population Radius Determination. 
integrating the effects of iodine 131 through 135. The population center distance equals the low population zone distance increased by a factor of one-third. Figure 2 shows the relationship between the inhalation and direct dose for various power levels. 
vI. COMPARISON OF ANALYTICAL METHOD TO EXISTING REACTOR SITES

\author{
As an indication of how the use of the above analytical method \\ results in distances reflecting current siting practices, the method was
}

Table VIII. Calculated Distances for Selected Keactors

\begin{tabular}{|c|c|c|c|c|c|c|}
\hline Reactor & $\begin{array}{l}\text { Power } \\
\text { Level } \\
{\stackrel{\text { Mw }}{t}{ }^{2}}^{2}\end{array}$ & $\begin{array}{l}\text { Exclusion } \\
\text { Calculated } \\
\text { Distance } \\
\text { (miles) }\end{array}$ & $\begin{array}{l}\text { Area } \\
\text { Actual } \\
\text { Distance } \\
\text { (miles) }\end{array}$ & $\begin{array}{c}\text { Low Population Area } \\
\text { Calculated } \\
\text { Distance } \\
\text { (miles) }\end{array}$ & $\begin{array}{c}\text { Population Ce } \\
\text { Calculated } \\
\text { Distance } \\
\text { (miles) }\end{array}$ & $\begin{array}{l}\text { ter Distance } \\
\text { Actual } \\
\text { Distance } \\
\text { (miles) } \\
\end{array}$ \\
\hline $\begin{array}{l}\text { Dresden } \\
\text { Con. Ed. } \\
\text { Yankee } \\
\text { * PRDC }\end{array}$ & $\begin{array}{l}630 \\
585 \\
485 \\
300\end{array}$ & $\begin{array}{l}0.50 \\
0.48 \\
0.42 \\
0.31\end{array}$ & $\begin{array}{l}0.50 \\
0.30 \\
0.50 \\
0.75\end{array}$ & $\begin{array}{l}7.4 \\
7.0 \\
6.3 \\
4.5\end{array}$ & $\begin{array}{l}9.9 \\
9.4 \\
8.4 \\
6.1\end{array}$ & $\begin{array}{r}14.0 \\
17.0 \\
21.0 \\
7.5\end{array}$ \\
\hline $\begin{array}{l}\text { PWR } \\
\text { Consumers } \\
\text { * Hallam } \\
\text { Pathfinder }\end{array}$ & $\begin{array}{l}270 \\
240 \\
240 \\
203\end{array}$ & $\begin{array}{l}0.31 \\
0.30 \\
0.30 \\
0.29\end{array}$ & $\begin{array}{l}0.40 \\
0.50 \\
0.25 \\
0.50\end{array}$ & $\begin{array}{l}4.1 \\
3.9 \\
3.9 \\
3.4\end{array}$ & $\begin{array}{l}5.6 \\
5.2 \\
5.2 \\
4.6\end{array}$ & $\begin{array}{r}7.5 \\
135.0 \\
17.0 \\
3.5\end{array}$ \\
\hline $\begin{array}{l}\text { PG\&E } \\
\text { * Phila.Elec. }\end{array}$ & $\begin{array}{r}202 \\
\text { - } 115\end{array}$ & $\begin{array}{l}0.29 \\
0.26\end{array}$ & $\begin{array}{l}0.25 \\
0.57\end{array}$ & $\begin{array}{l}3.4 \\
2.4\end{array}$ & $\begin{array}{l}4.6 \\
3.2\end{array}$ & $\begin{array}{r}3.0 \\
21.0\end{array}$ \\
\hline $\begin{array}{l}\text { NASA } \\
\text { CVTE } \\
\text { EIk River } \\
\text { VBWR } \\
\text { * Piqua }\end{array}$ & $\begin{array}{l}60 \\
60 \\
58 \\
50 \\
48\end{array}$ & $\begin{array}{l}0.22 \\
0.22 \\
0.22 \\
0.21 \\
0.21\end{array}$ & $\begin{array}{l}0.50 \\
0.50 \\
0.23 \\
0.40 \\
0.14\end{array}$ & $\begin{array}{l}1.6 \\
1.6 \\
1.5 \\
1.4 \\
1.4\end{array}$ & $\begin{array}{l}2.1 \\
2.1 \\
2.0 \\
1.9 \\
1.8\end{array}$ & $\begin{array}{r}3.0 \\
25.0 \\
20.0 \\
15.0 \\
27.0\end{array}$ \\
\hline
\end{tabular}

*NOTE: These reactors are not water moderated and are included in the table for illustrative purposes only. The distances for all reactors were based on the same assumption with respect to fission product release from the fuel and containment vessel and the subsequent dispersal events. There can be considerable differences between reactor types in the events that could result in a major accident and the releases that might be experienced. This must be examined on an individual basis for each reactor and the distances determined accordingly. 
applied to a number of reactor projects that have been proposed or are currently authorized for construction. These results are given in Table VIII. 


\section{APPENDIX}

\section{A. Relationship of the Sutton Diffusion Parameter and the Generalized}

\section{Gaussian Parameter}

The traditional form of the 0 . G. Sutton atmospheric diffusion equation describing the centerline concentration downind of a continuous point source is generally written:

$$
\frac{w}{Q^{2}}=\frac{1}{r \vec{u} c_{y} c_{z} d^{2-n}}
$$

This equation was based on an extension of diffusion theory, an assumed homogeneous isotroplc source, and an assumed three dimensional Gaussian distribution model.

When the receptor and cloud centerline are colncident with the ground level, the concentration is assumed to be doubled as a consequence of "ground reflection":

$$
\frac{x}{Q^{\prime}}=\frac{2}{\pi \bar{u} c_{y} c_{z} d^{2-n}}
$$

The diffusion coefficients, $C_{y}$ and $C_{z}$ are mathematical quantities which represent the diffusion capability of the atmosphere. However, Sutton and others found it necessary to determine values of $C_{y}$ and $C_{z}$ Indirectly from data obtained through experimental field measurement. By expressing the diffusion coefficients in terms of standard deviations of the Geussian distribution model which is assumed to describe the spacial relationship of cloud 
concentration, the resulting equation may be written in the more useful form:

$$
\frac{x}{Q^{\prime}}=\frac{1}{\pi \bar{u} \sigma_{y}} \sigma_{z}
$$

Where:

$$
\begin{aligned}
& \sigma_{\mathrm{y}} \text { and } \sigma_{\mathrm{z}} \text { are the standard deviations of the cloud } \\
& \text { concentration in the vertical and horizontal direc- } \\
& \text { tions, respectively. }
\end{aligned}
$$

The factor of two which was introduced for "ground reflection" has been included in this equation. The equation in this form, with the Gaussian parameters, permit direct interpretation of experimental data obtained from fleld measurements.

The relationship between the generalized diffusion parameters and the more familiar sutton parameters (4) are expressed as!

$$
\begin{aligned}
& \sigma_{y}=\frac{1}{\sqrt{2}} c_{y} d^{1-n / 2} \\
& \sigma_{z}=\frac{1}{\sqrt{2}} c_{z} d^{1-n / 2}
\end{aligned}
$$

In the generallzed form, the perameters $\sigma_{\mathrm{y}}$ and $\sigma_{\mathrm{z}}$ are functions of distence and can be approximated directly from anemoneter records if appropriate averaging techniques are supplied (7).

\section{B. Bibliography}

The following reference documents contain information pertaining to data obtained from various reactor projects and from associated analytical programs. The following list constitutes a brief summary of the information available on certain factors pertinent to reactor siting.

1. McCullough, C. R., Safety Aspects of Nuclear Reactors, D. Van Nostrand Company, Inc., Princeton, New Jersey, 1957.

2. Rockwell, T., "Reactor Shielding Design Mamal", TID-7004, March 1956. 
3. Ritchie, R. H., "Dosimetry Aspects of Nuclear Accidents", Nuclear Safety, 2(1) pp 71-75, September 1960.

4. Culver, H. N., Maximum Credible Accident Exposures at Reactor Site Boundaries", Mhclear Safety, 2(1) pp 83-96, September 1960.

5. Progress in Muclear Sefety - Series 4, "Technology, Engineering and Safety", Hurst, R., Iyon, R. N., and Nicholls, C. M. - Editors, Pergamon Press, New York, New York, 1960.

6. Brittan, R. O., "Reactor Containment", ANI-5948, May 1959.

\section{List of Srmbols and Definitions}

Symbol

$A_{\tilde{\tau}}$
$B_{y}, C_{z}$
$d$
$D^{\prime}$
$D_{T}, D_{\infty}$
$D_{\gamma}$
$\bar{E}$
$E_{\text {avg }}$
$E_{\gamma}$
$f_{a}$

Amount of radioactive material inhaled by an individual during a specific time period.

Build up factor.

Meteorological virtual diffusion coefficients in the vertical and horizontal planes, respectively.

Distance from the source of radiation or release point.

Dose rate delivered by an exposure to radiation.

Dose delivered during time interval "T" or infinite time.

Dose delivered by direct exposure to gamma radiation.

Effective energy absorbed by the critical organ per disintegration.

Average energy assumed for selecting values of $\mu$.

Total gamma energy emitted per disintegration.

Fraction of inhaled material which is subsequently deposited in the critical

organ.

Fraction of material released to the reactor building and available to be released to the atmosphere.

Fraction of inventory released from the primary system to the reactor building.
Dimensions

curies

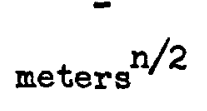

meters

$\operatorname{rads} \cdot \sec ^{-1}$

rads

rads

$\mathrm{Mev} \cdot \mathrm{dis}^{-1}$

Mev'dis ${ }^{-1}$

Mev.dis ${ }^{-1}$ 
Symbol

k

m

n

$\mathbf{P}$

Po

$q_{8}$

$q_{t}$

$Q_{\tau}$

R

$s_{0}, s_{5}$

$t, T$

To

$T_{b}, T_{e}, T_{r}$

$\bar{u}$

$\tau, \tau_{1}, \tau_{2}$

$\sigma_{\mathrm{y}}, \sigma_{\mathrm{z}}$

$\gamma_{1}$

$\lambda_{b}, \lambda_{e}, \lambda_{r}$

$\lambda_{1}$

$\mu, \mu_{a}$
Represents

Linear absorption constant, $\left(\frac{\mu-\mu_{a}}{\mu_{2}}\right)$.

Mass of the critical organ.

Meteorological stability parameter.

Rated reactor power level.

Unit reactor power ( 1 megawatt).

Saturated reactor inventory for a

specific isotope.

Reactor inventory for a specific

isotope after a finite operating

time.

Amount of a specific isotope released to the atmosphere during a finite time

interval per megawatt reactor power.

Breathing rate.

Source terms at shutdown - total and released to reactor bullding.

Time variables.

Reactor operating time.

Blological, effective, and radiological half-Iives.

Average wind speed.

Exposure time intervals.

Standard deviations of cloud concentration.

Fission yield.

Biological, effective, and radiological

elimination and decay constants.

Leak rate from the containments shell

(reactor building)

Inear and energy absorption coefficients
Dimenstons

grams

$M_{t}$

curles

curies

curies: $\mathrm{Nw}^{-1}$

meters ${ }^{3} \cdot \sec ^{-1}$

Mev. sec $c^{-1} \cdot \mathrm{Mw}^{-1}$

seconds

seconds

seconds

meters'sec ${ }^{-1}$

seconds

nuclel-fission ${ }^{-1}$

second ${ }^{-1}$

$\operatorname{second}^{-1}$

meter ${ }^{-1}$ 


\section{REFERENCES}

1. "Reactor Site Criteria", Title 10, Code of Federal Regulations, Part 100 (10 CFR 100), February 11, 1961.

2. "Theoretical Possibilities and Consequences of Major Accidents in Large Nuclear Power Plants, "WASH-740, March 1957.

3. "Permissible Dose From External Sources of Ionizing Radiation", NBS Handbook No. 59, w/addendum of April 1958, September 24, 1954.

4. Sutton, 0. Go., "A Theory of Eddy Diffusion in the Atmosphere", Proceedings of the Royal Society (London), 135A:143, 1932.

5. "Meteorology and Atomic Energy", AECU-3066, July 1955.

6. Gifford, F. A. Jr., "Use of Routine Meteorological Observations for Estimating Atmospheric Dispersion", Nuclear Safety, 2(4) pp 47-51, June 1961.

7. Meade, P. J., "Meteorological Aspects of the Safety and Location of Reactor Plants", World Meteorological Organization, Technical Note No. 33, pp 13-22, 1960.

8. Hosler, C. R., "Low-Level Inversion Frequency in the Contiguous United States", Monthly weather Review, 89 pp 319-339, September 1961.

9. Beattie, J. R., "An Assessment of Environmental Hazards from Fission Product Keleases", AHSB(S) R9, May 1961.

10. "Report of ICRP Committee II on Permissible Dose for Internal Radiation (1959)", Health Physics (Journal), Volume 3, June 1960.

11. Blomeke, J. O. and Todd, M.F., "Uranium-235 Fission Product Production as a Function of Thermal Neutron Flux, Irradiation Time, and Decay Time", OKNL-2127, Part 1, Volume 1 and 2, November 1958.

12. Goldstein, H., The Attentuation of Gamma Rays and Neutrons in Reactor Shields, May 1957.

13. The Reactor Handbook, AECD-3645, Volume 1, "Physics", February 1955.

14. Gifford, F. A. Jr., "Atmospheric Dispersion Calculations Using the Generalized Gaussian Plume Model", Nuclear Safety, 2(2) pp 56-59, December 1960. 